Journal of

Molecular Microbiology

and Biotechnology

\title{
Metagenomics for Mining New Genetic Resources of Microbial Communities
}

\author{
Manuel Ferrer ${ }^{a} \quad$ Ana Beloqui ${ }^{a} \quad$ Kenneth N. Timmis ${ }^{b, c}$ Peter N. Golyshin ${ }^{b, c}$ \\ ${ }^{a}$ Institute of Catalysis, CSIC, Madrid, Spain; ${ }^{b}$ Division of Microbiology, HZI - Helmholtz Centre for \\ Infection Research, and 'Institute of Microbiology, Technical University of Braunschweig, Biozentrum, \\ Braunschweig, Germany
}

\section{Key Words}

Biotransformation • Metagenome • Protein engineering • Shotgun

\begin{abstract}
Recent progress has revealed that the capture of genetic resources of complex microbial communities in metagenome libraries allows the discovery of a richness of new enzymatic diversity that had not previously been imagined. Activitybased screening of such libraries has demonstrated that this new diversity is not simply variations on known sequence themes, but rather the existence of entirely new sequence classes and novel functionalities. This new diversity, the surface of which has thus far only been scratched, constitutes potential for a wealth of new and improved applications in industry, medicine, agriculture, etc., and promises to facilitate in a significant manner our transition to a sustainable society, by contributing to the transition to renewable sources of energy, chemicals and materials, the lowering of pollutant burdens, lower processes energies, etc. Current bottlenecks in metagenomics include insufficient functional characterization and amplifying non-validated annotations of proteins in databases.

Copyright $\odot 2008$ S. Karger AG, Basel
\end{abstract}

\section{Introduction: Biotechnological Importance and Potential of Biological Catalysts}

Biological catalysts, enzymes, have been exploited for decades to effect chemical and biochemical reactions of utility in the food industry and chemical industries and in medicine, and currently their application is rapidly increasing as a result of efforts to increase the diversity of products and applications in the marketplace, improve efficiencies and reduce costs, reduce energy needs (e.g. in chemicals production, in washing powders, etc.), and to reduce the environmental burden of industrial processes. Particularly interesting are efforts to explore the potential of enzymes to mediate new reactions that are difficult or expensive through chemical catalysis, to create new medicaments, and to facilitate transformation of our current fossil fuel-based economy to a renewables-based economy [Alcalde et al., 2006; Schmid et al., 2001].

Though a chemically rather homogeneous class of catalysts, enzymes collectively catalyze a vast array of chemical reactions that characterize life processes. They also differ from chemical catalysts in often being exquisitely regio- and enantioselective and, yet simultaneously relatively unspecific in terms of substrate selectivity. These properties are often strongly influenced by context - the

\section{KARGER \\ Fax +4161306 1234 \\ E-Mail karger@karger.ch}

www.karger.com
(C) 2008 S. Karger AG, Basel

$1464-1801 / 09 / 0162-0109 \$ 26.00 / 0$

Accessible online at:

www.karger.com $/ \mathrm{mmb}$
Kenneth N. Timmis

Microbial Ecology Department

HZI - Helmholtz Centre for Infection Research

DE-38124 Braunschweig (Germany)

Tel. +495316181 401, Fax +495316181 411, E-Mail kti@helmholtz-hzi.de 
prevailing cellular $\mathrm{pH}$, ionic strength, solute nature and concentration, participation in multienzyme complexes, local substrate or product concentrations, etc. - and so the enormous natural diversity of catalytic activities can often be expanded by exploration of new environmental contexts of reaction conditions.

It is therefore no wonder that the topic of biocatalysis is 'hot' and that major efforts are underway to explore biocatalytic diversity and harness it for existing and new applications. Increasing pressure to develop new medicines, materials, healthier foods, less expensive chemicals, less polluting processes, lower energy needs, more sustainable practices, etc. are forces driving such efforts, and globalization, on one hand, and political pressure to enable industry to function on a supply base less influenced by politically unstable or unfriendly regimes, on the other, are other important drivers.

The race is therefore on to explore the range and limits of biocatalytic diversity and applicability. This involves the accessing of natural enzyme diversity, exploration of the inherent wider catalytic potential of enzymes in relation to possible or relevant reaction contexts, and optimization by tailoring and fine tuning of promising activities for applications. In this review, we will focus on the former, namely recent advances in enzyme discovery.

\section{Accessing Enzyme Diversity}

\section{Homology-vs. Activity-Based Enzyme Mining}

The traditional means of accessing enzyme diversity is to search for an organism expressing the desired activity, and to optimize the production and recovery of the enzyme, often by cloning its gene and hyperexpressing it in an appropriate host. With the advent of genomics, another discovery channel opened up, namely data mining: sequence gazing for open reading frames with homology to the sequences of known enzymes. These may then be cloned and hyperexpressed, and the activities of the gene products characterized. However, it rapidly became apparent that a large proportion of the open reading frames of newly-sequenced genomes have little sequence homology with known enzymes, so their potential activities remain hidden. To partly circumvent this problem, strategies involving the construction of genomic expression libraries - large coverage, small insert libraries in vectors possessing powerful expression signals - and their activity screening, often with automated high-throughput methods, have been developed. This strategy does not rely on sequence homologies for enzyme detection, and often reveals new sequence classes and phylogenetic branches of enzymes with classical activities, and sometimes new activities. Where applicable, therefore, it is the method of choice to capture the greatest enzyme diversity.

\section{Metagenomics}

Most enzymes in current use are of microbial origin, and it is widely appreciated that the microbial world contains by far the greatest fraction of biodiversity in the biosphere, so it is the microbes that will deliver the greater part of enzyme diversity and the majority of new applications. However, the well-known dilemma of microbes that the majority cannot be cultivated - limits application of the traditional means of enzyme discovery described above. The anticipated rich enzymatic pickings from the uncultured microbial majority has stimulated the development of new genomics-based discovery approaches, the so-called 'metagenomics' or environmental genomics approaches. These are often described as culture-independent approaches and, in terms of the organisms being accessed and mined, this is the case. However, the need for large amounts of cell biomass for enzyme screening and isolation always requires cultivation of a producer microbe. The difference here is that cultivation refers to that of a surrogate organism - the host exploited for archiving and expressing the harvested genetic resources. Metagenomics is analogous to genome library construction and screening, with the difference that the 'genome' cloned is not from a single characterized laboratory clone, but rather from the entire microbial community present in an environmental sample: it is the 'community genome'. 'Genome' coverage in this case is an ephemeral notion, since different community members will be present in different numbers in the sample, and their genomes will be extracted with different efficiencies, so genes of different organisms will be present in very different concentrations in the DNA used to construct the libraries. For this reason, attempts to obtain (or even calculate the size of) a library providing good coverage of all genomes present in a sample are rare and limited to samples from extreme environments, known to contain microbial communities of very limited complexity and diversity.

There are two distinct strategies taken in metagenomics, according to the primary goal. Large insert libraries are constructed for archiving and sequence homology screening purposes: to capture the largest amount of the available genetic resources available in the sample and archive it for further studies/interrogation. Though some 
genes in such libraries are expressed and may be found in activity screens, these will be biased towards genes from organisms related to the host, since they will generally lie far from vector expression signals and therefore be expressed from their own expression signals. Large contiguous DNA fragments are an important advantage of above libraries as they provide better taxonomic affiliation of the source organism(s). Small insert expression libraries, especially those made in lambda phage vectors, are constructed for activity screening. The small size of the cloned fragments means that most genes present in the appropriate orientation will be under the influence of the extremely strong vector expression signals, and thus have a good chance of being expressed and detected by activity screens. Moreover, the significant problem of 'lethal' genes and gene products, whether sought or accompanying sought genes, on the cloned DNA, is circumvented, since the host is killed anyway by the phage infection. Though these two strategies are conceptually distinct, in fact both are increasingly used together, because of their complementarities: activity mining often reveals novel enzymes, but the nature of the organism from which they originate can rarely be determined, nor can their genetic context, which may harbor equally or even more interesting similar or related enzymes. Primary enzyme discovery in an expression library, followed by identification of the same gene in a large insert library and genome sequencing the identified fragment, constitutes a powerful means of maximizing the discovery process and identifying the interesting new organisms that are producing such enzymes.

Microbial diversity is not limited to prokaryotes: eukaryotic microbial diversity is also enormous, and hence of great interest for exploration of functional diversity. Because of the problem of introns in eukaryotes, considerable effort has been invested in the creation of cDNA libraries from RNA. This requires isolation of full-length mRNAs, reverse transcribing them, and cloning the cDNA to create the libraries. Here, the RNA extraction technique is critical, since it needs to extract RNA from thick-walled structures, like spores and yeast cells. An example of cDNA libraries is those produced from algal mat samples, in which clones matching mainly prokaryotic but also eukaryotic protein sequences, such as from dust mite Lepidoglyphus destructor, Gossypium hirsutum and Branchiostom belcheri were found [Grant et al., 2006].

\section{Microbial Diversity}

The principal measure of phylogenetic relatedness, and thus of biodiversity, is the sequence of the $16 \mathrm{~S}$ ribosomal RNA gene in prokaryotes and its equivalent $18 \mathrm{~S}$ rRNA gene in eukaryotes. Determination of very large numbers of such sequences has revealed that natural environments contain vast numbers of diverse microorganisms (see examples in table 1), and that more than $99 \%$ of those present in many such habitats have not yet been cultured in the laboratory. A current estimate is that soil and the Earth's oceans are teeming with some $4-5 \times 10^{30}$ and $3.6 \times 10^{29}$ microbial cells, respectively [Cowan et al., 2005; Deutschbauer et al., 2006; Green and Keller, 2006; Sogin et al., 2006]. This enormous biodiversity, comprised of 52 large phyla [Dumont et al., 2006], is even larger if viruses are included, since approximately $10^{7}$ particles of virus size per $\mathrm{ml}$ of seawater have been found, most of which are bacteriophages [Angly et al., 2005, 2006; Breitbart et al., 2004; Breitbart and Rohwer, 2005; Culley et al., 2006]. These complex uncultured communities represent an enormous unexplored reservoir of genetic and metabolic diversity. Systematic characterization of this diversity will not only yield novel functionalities but also provide new understanding of metabolic activities and interdependencies underlying microbial life in diverse habitats, and the roles of individual microorganisms in the ecosystem, and thereby yield new insights and clues that will aid the cultivation of currently uncultured microbes.

\section{Metagenome Sequencing}

Over the past decade, a number of studies have been reported that explore environmental microorganisms in a culture-independent manner by metagenomics - isolating DNA from environmental samples and generation of large clone libraries of this whole-community DNA [Edwards and Rohwer, 2005; Green and Keller, 2006; Tyson and Banfield, 2005]. In the case of simple microbial communities containing only a few different microbes, sequencing of enough clones of the libraries may allow their genomes to be reconstructed [Tyson et al., 2004], the annotation of which may yield possible explanations of community composition and functionalities, and insights that suggest new hypotheses about functional interactions. These can then be tested by analyzing gene expression in situ and/or under controlled in vitro conditions, using microarrays and real-

J Mol Microbiol Biotechnol 2009;16:109-123 
Table 1. Recent examples of sequencing and sequence analysis of gene libraries from different environments

\begin{tabular}{|c|c|c|}
\hline Environment & Major findings and/or species & Reference \\
\hline Gold-bearing metagenome & $\begin{array}{l}\text { Acidithiobacillus, Leptospirillum, Sulfobacillus, Shingomonas } \\
\text { and Ferroplasma spp. }\end{array}$ & Chen et al., 2006 \\
\hline Acid mine drainages of Yunfu sulfide mine & $\begin{array}{l}15 \text { operational taxonomic units (putative Nitrospira and } \\
\alpha / \beta / \gamma \text {-Proteobacteria) }\end{array}$ & He et al., 2006 \\
\hline Deep-sea plankton (Antarctic Polar Front) & New group of a marine group II euryarchaeote & Moreira et al., 2004 \\
\hline Mesopelagic Antarctic plankton & 2 novel divergent Deltaproteobacteria & Moreira et al., 2006 \\
\hline Mediterranean Sea $(3,000 \mathrm{~m})$ & 1,621 new $16 \mathrm{~S}$ rRNA sequences (>97\% similarity) & Zaballos et al., 2006 \\
\hline Polar Greenland Sea $(2,000 \mathrm{~m})$ & 1,621 new $16 \mathrm{~S}$ rRNA sequences (>97\% similarity) & Zaballos et al., 2006 \\
\hline Oceanic regions (including Arctic) & 184 viral assemblages & Angly et al., 2006 \\
\hline Near-shore marine-sediment & $10^{4}$ viral genotypes per $\mathrm{kg}$ of sediment & Breitbart et al., 2004 \\
\hline Suboxic sediment of the Black Sea & $\begin{array}{l}\text { Crenarchaeote with a unique ammonia monooxygenase- } \alpha \\
\text { subunit }(a m o A) \text { gene }\end{array}$ & Francis et al., 2005 \\
\hline \multirow[t]{2}{*}{$\begin{array}{l}\text { Sorcerer II Global Ocean Sampling } \\
\text { Expedition }\end{array}$} & $\begin{array}{l}\text { An overwhelming sequencing effort ( } 6.3 \text { billion bp) which } \\
\text { delivered a largest microbial dataset ever }\end{array}$ & Rush et al., 2007 \\
\hline & $\begin{array}{l}\text { Analysis of } 7.7 \text { million global ocean sampling sequences } \\
\text { suggests almost linear increase of numbers of new protein } \\
\text { families with input of new sequences }\end{array}$ & Yooseph et al., 2007 \\
\hline Alpine grassland soils & Diversity of $\mathrm{N}_{2}$-fixing populations & Gros et al., 2006 \\
\hline Saltern crystallizer & Haliphilic archaeon Haloquadrum walsbyi & Legault et al., 2006 \\
\hline Pesticide-contaminated agriculture soil & 46 different phylotypes (Proteobacteria and Actinomycetes) & Paul et al., 2006 \\
\hline Pleistocene cave bears & 26,861 base pairs of cave bear genome sequence & Noonan et al., 2005 \\
\hline $\begin{array}{l}\text { Uncultured bacterial symbiont of worm } \\
\text { (anoxic coastal sediments) }\end{array}$ & Sulfur-oxidizing and sulfate-reducing bacteria & Woyke et al., 2006 \\
\hline Human distal gut microbiome & 78 million basepairs of microbial genomes & Gill et al., 2006 \\
\hline
\end{tabular}

time polymerase chain reaction (PCR), and subsequent structural and functional protein analyses. This information builds a continuously expanding compendium of knowledge about the genomes of all microorganisms in a particular environment, independently of the ability to culture them. This organism information gathering trajectory is complemented by current mega-shotgun sequencing of environmental DNA-metagenome sequencing uncoupled from the organisms in the environments studied - such as that of the Sargasso Sea [Venter et al., 2004], worm symbioses [Woyke et al., 2006], human distal gut microbiome [Gill et al., 2006; Manichanh et al., 2006], Pleistocene cave bears [Noonan et al., 2005] and coastal virus communities [Breitbart et al., 2004; Culley et al., 2006]. Of special interest are two landmark publications [Rusch et al., 2007; Yooseph et al., 2007] that describe the generation and analysis of 7.7 million sequencing reads ( 6.3 billion bp), from the largest sequencing effort ever undertaken. This has produced a huge genomic dataset of microbiota inhabiting the seawater from Northwest Atlantic to Eastern Tropical Pacific and whose analysis will keep busy ecologists, evolutionists, structural genomicists, environmental microbiologists and scientists of many other disciplines in the years to come.

Although shotgun sequencing of environmental DNA constitutes an attractive approach to obtaining genomic information on yet uncultured microbes, the seminal work of Holmes [2003], Torsvik [2002] and Johnson and Slatkin [2006] established that most microbial communities are extremely complex and since high-throughput sequencing yields a large number of relatively short reads, whose average length normally is, depending on sequencing method, between 80 and 1,000 bp, it results in artificial contiguous assemblies of DNA sequences derived from different hosts [DeLong, 2005; Noguchi et al., 2006; Tyson and Banfield, 2005]. Because of inherent variations within most environments, and the complexity of metagenomic DNA, it has been suggested that high-quality genome assembly should not be attempted with metagenomic libraries, but rather that they should be exploited to explore microbial genetic diversity and to mine for new activities and products. 
Fig. 1. Different approaches for metagenome mining for new activities.

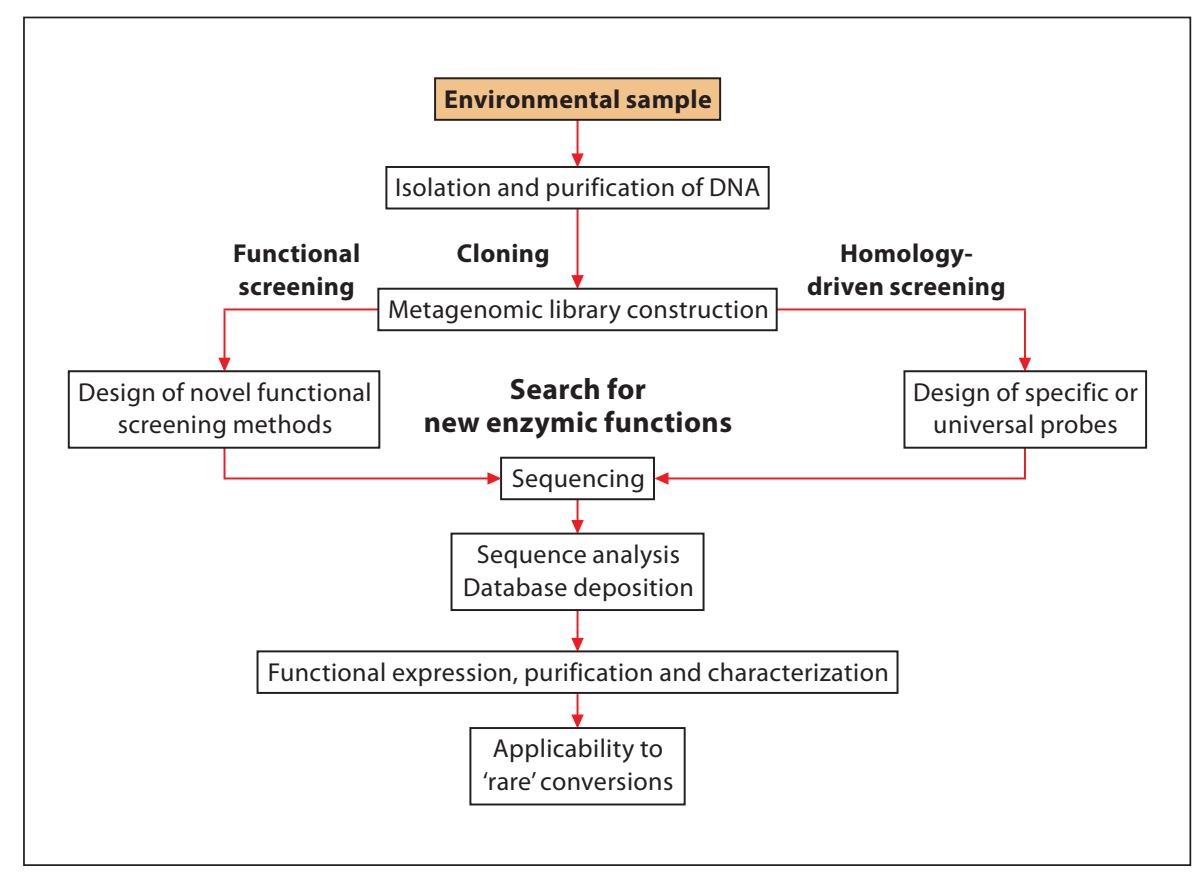

\section{Sequence Homology-Based Enzyme Discovery}

Enzyme discovery through (meta)genomics generally involves sequence- or activity-based strategies (fig. 1). The former is conveniently carried out through construction of PCR-amplified small clone libraries that can be handled with high-throughput facilities. The PCR-based approach is predicated on the identification, by sequence comparisons of members of the enzyme class of interest, of highly conserved functional motifs for the design of primers for PCR amplification in, and gene probing of, DNA libraries. Although this strategy led to the identification of new enzymes, like $\beta$-lactamases, sulfur oxygenase reductases, chitinases, alcohol oxidoreductases, monooxygenases, diol dehydratases, carboxypeptidases and antibiotic resistance genes (table 2), from a variety of environments, including pesticide-contaminated sites [Paul et al., 2006], the Mediterranean Sea [Zaballos et al., 2006], a crystallizer pond [Legault et al., 2006], water columns and sediments of the ocean [Francis et al., 2005], the Delaware River [Cottrell et al., 2005], gold-bearing concentrates [Chen et al., 2006], and other environmental resources [Holmes et al., 2003], it has the major limitation that it relies on known protein structures, and thus cannot enable discovery of new protein classes (either with the same catalytic activity or with different catalytic activities for the offered substrate) with sequence elements that differ from the conserved sequences of the primers. For example, among 8,823 clones of a metagenomic library from the cold-seep sediments of Edison seamount (10,000 years old), 30 clones producing $\beta$-lactamases exhibited considerable gene sequence diversity, as revealed by banding patterns of PCR amplification with designed primers, but a similar activity spectrum limited to penicillins and early cephalosporins and not to most modern $\beta$-lactam antibiotics [Seong et al., 2005]. For other examples of limited novelty retrieved by the sequence-based mining approach, see LeCleir et al. [2004] and Bown et al. [2004]. Thus, although PCR screening of metagenome libraries is a powerful approach to mine new but related enzymes known to have industrial interest, it yields few really novel enzymes.

A number of new developments of PCR-based gene probing of metagenomes have been described recently. One is based on substrate hybridization capture using magnetic beads. Briefly, multiple target genes are PCRamplified, using gene-specific degenerate primers, and the partial gene amplicons are immobilized on streptavidin-covered magnetic beads, and used as hybridization probes to recover 'full-length' genes from metagenomic samples. This method has been used to capture new bacterial multicopper oxidases [Meyer et al., 2007]. Capture methods have been also applied in the human gut mobile metagenome [Jones and Marchesi, 2006]. In this case the 


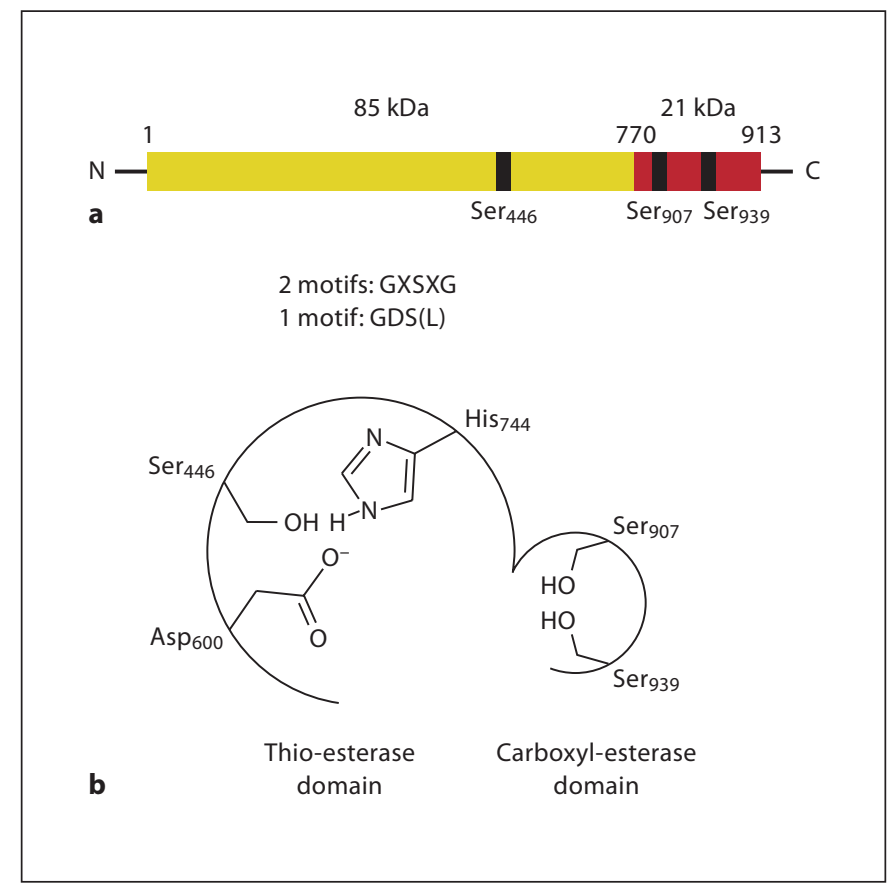

Fig. 2. Structural features of a novel esterase (O.16) mined from Urania basin. As shown, $\mathrm{O} .16$ contains 3 catalytic serines mediating different activities in two domains. a Schematic representation of the two domains. b Location of catalytic serines.

method relies in a culture-independent transposon-aided capture method (TRACA), which facilitates acquisition of plasmids harboring genes for phosphoesterases or phosphohydrolases and facilitate the maintenance and selection in Escherichia coli hosts.

\section{Activity-Based Enzyme Discovery}

\section{Functional Screens}

Activity-based screening of metagenome libraries, though often more laborious than PCR-based procedures, is not dependant on previous knowledge and can yield fundamentally new knowledge. In its simplest form, it involves a simple color reaction mediated by the enzyme sought, in conjunction with a substrate incorporated into, or subsequently added to, the agar plate/microtiter plate on/in which the library is propagated. But there are many more complicated versions. Such screens identify catalytic activities: subsequent isolation of the responsible protein(s) not infrequently reveals enzymes unrelated to those currently known. For example, from a metagenome library created from the seawater:brine interface of the Urania West Basin, a hypersaline anoxic deep sea basin off the coast of Crete, 5 distinct groups of esterases were obtained, 2 of which exhibited no homology to known esterases [Ferrer et al., 2005a]. They had activity optima at high pressure and salinity. One designated 0.16 that was studied in detail uniquely had two catalytic domains mediating two distinct activities, a thioesterase and a carboxyl esterase activity (fig. 2), containing three catalytic centers, and exhibited an adaptive tertiary-quaternary structure that alters between three molecular states, according to the prevailing physicochemical conditions. It thus has a level of structural and functional complexity higher than other known esterases. Interestingly, some of the esterases have high activities, specificities, enantioselectivities, and exceptional stability in polar solvents, and are therefore potentially useful for industrial biotransformations. One possesses the highest reported enantioselectivity towards solketal acetate, a chiral synthon for the synthesis of certain drugs, e.g. for AIDS. A metagenome study of the rumen of a New Zealand dairy cow revealed that a substantial fraction of the enzymes of all of the enzyme classes studied had no significant homology to known enzymes, and thus is a mine of novel and unusual enzymes [Ferrer et al., 2005b]. Such enzymes exhibited activities of industrial interest, for example for the synthesis of novel nutritional lipids with therapeutic properties [Reyes-Duarte et al., 2005] and for the bioconversion of polyphenolic compounds [Beloqui et al., 2006]. The latter study has also identified a new laccase lacking homology to known laccases, but containing a common domain of unknown function, and thereby revealed the function of a large protein family (about 750 database entries) conserved in Bacteria. This result emphasizes another important output of activity mining of metagenome libraries, namely the progressive identification of proteins of unknown function and the correction of incorrect functional assignments to protein sequences in the databases, the problem of growing proportions for bioinformatics analyses of genomic data and analyses based on such analyses, as in systems biology.

With ongoing screening methods a high success rate of the activity-based mining of metagenomes for new enzymatic industrial activities has univocally demonstrated the importance of microbial diversity in the discovery of new enzymes and underlines the necessity of mining different environments to capture new activities potentially applicable for biotechnology, including carboxyl-hydrolases (esterases, lipases, lactamases), polysaccharide-modifiying enzymes (cellulases, $\alpha$-amylases, xyla- 
Table 2. Functional mining of enzymatic activities

\begin{tabular}{|c|c|c|c|}
\hline Enzyme & Source & $\begin{array}{l}\text { Screening } \\
\text { method }\end{array}$ & Reference \\
\hline \multirow[t]{12}{*}{ Esterases } & Deep-sea sediment & Functional & Park et al., 2006 \\
\hline & Soil from the forest, samples of mud flats and beaches & Functional & Kim et al., 2006 \\
\hline & $\begin{array}{l}\text { Mud and sediment-rich water from Cislock (Lipukang, Tangkuban and } \\
\text { Silerei areas of Indonesia) }\end{array}$ & Functional & Rhee et al., 2005 \\
\hline & Drinking water collected near Wietze (Germany) & Functional & Elend et al., 2006 \\
\hline & Deep hypersaline anoxic basin 'Urania' (Eastern Mediterranean Sea) & Functional & Ferrer et al., 2005a \\
\hline & Drinking water & Functional & Elend et al., 2006 \\
\hline & Soil/sediment samples (mudflats, beaches and forests) & Functional & Kim et al., 2006 \\
\hline & Soil (not specified) & Functional & Byun et al., 2006 \\
\hline & Kenyan soda lakes, Lake Elmenteita and Crater Lake & Functional & Rees et al., 2003 \\
\hline & Mud holes in solfatara fields & Functional & Rhee et al.,, 2005 \\
\hline & Cow rumen & Functional & Ferrer et al., 2005 \\
\hline & Cow rumen & Functional & Reyes-Duarte, 2005 \\
\hline \multirow[t]{4}{*}{ Lipases } & Tidal flat sediment & Functional & Lee et al., 2006 \\
\hline & Pond water & Functional & Ranjan et al., 2005 \\
\hline & Forest topsoil from Yuseong (Daejeon, Korea) & Functional & Lee et al., 2004 \\
\hline & Soil and compost (origin not specified) & Functional & Lämmle et al., 2007 \\
\hline Phosphatases & Soil and compost (origin not specified) & Functional & Lämmle et al., 2007 \\
\hline \multirow[t]{2}{*}{$\beta$-Lactamases } & Cold-seep sediments of Edison Semount (south of Lihir Island, Papua New Guinea) & PCR & Soeng et al., 2005 \\
\hline & Cold seep sediments & PCR & Soeng et al., 2005 \\
\hline \multirow[t]{2}{*}{ Amylolytic enzymes } & Seoho stream junction (Suwon, South Korea) & Functional & Yun et al., 2004 \\
\hline & Moss covered sludge & Functional & Yun et al., 2004 \\
\hline$\beta$-Glucanases & Mice gut & Functional & Walter et al., 2005 \\
\hline \multirow[t]{4}{*}{ Cellulases } & Soil (not specified) & Functional & Voget et al., 2006 \\
\hline & Cow rumen & Functional & Ferrer et al., 2005b \\
\hline & Kenyan Soda Lakes, Elmenteita Lake and Crater Lake & Functional & Rees et al., 2003 \\
\hline & Chukchi Sea & PCR & Cottrell et al., 2005b \\
\hline \multirow[t]{2}{*}{ Chitinases } & $\begin{array}{l}\text { Diverse aquatic habitats: Sargasso Sea and hypersaline alkaline lake (Mono Lake, } \\
\text { California) }\end{array}$ & PCR & LeCleir et al., 2005 \\
\hline & Delaware Bay estuary & Functional & Cottrell et al., 1999 \\
\hline \multirow[t]{2}{*}{ Xylanases } & Human gut & Functional & Hayashi et al., 2005 \\
\hline & Insect guts (thermites and moths) & Functional & Brennan et al., 2004 \\
\hline Pectinases & Soils from tropical areas & Functional & Solbak et al., 2005 \\
\hline \multirow[t]{2}{*}{ Cyclodextrinases } & Cow rumen & Functional & Ferrer et al., 2005b, 2007 \\
\hline & Soil sediments & Functional & Tang et al., 2006 \\
\hline Chitinases & Larvae of tiomato moth (Lacanobia oleracea) & Functional & Fitches et al., 2004 \\
\hline \multicolumn{4}{|l|}{ Poly-3-hydroxybutyrate } \\
\hline \multirow[t]{3}{*}{$\begin{array}{l}\text { Alcohol/aldehyde } \\
\text { oxidoreductases }\end{array}$} & $\begin{array}{l}\text { Soils from sugar beet field (Göttingen, Germany), River Grone (Germany), } \\
\text { and Solar Lake (Egypt) and sediment soil (with enrichment) }\end{array}$ & $\begin{array}{l}\text { Functional } \\
\text { and PCR }\end{array}$ & Knietsch et al., 2003a, b \\
\hline & Waster water treatment plant & Functional & Wexler et al., 2005 \\
\hline & Forest soil from Jindong Valley (Korea) & Functional & Lim et al., 2005 \\
\hline \multirow[t]{3}{*}{ (Mono/di)oxygenases } & Eastern Snake River plain basaltic aquifer; forest soil from Jindong Valley (Korea) & $\begin{array}{l}\text { PCR/ } \\
\text { Functional }\end{array}$ & Erwin et al., 2005; \\
\hline & Upland soil (Marburg, Hesse, Germany) & PCR & Ricke et al., 2005 \\
\hline & Soil and compost (origin not specified) & Functional & Lämmle et al., 2007 \\
\hline Polyphenol oxidase & Cow rumen & Functional & Beloqui et al., 2006 \\
\hline $\begin{array}{l}\text { Glycerol dehydratase and } \\
\text { diol dehydratase }\end{array}$ & $\begin{array}{l}\text { Soils from sugar beet field (Göttingen, Germany), River Grone (Germany) } \\
\text { and Solar Lake (Egypt) }\end{array}$ & PCR & Knietsch et al., 2003a \\
\hline \multirow[t]{2}{*}{ Amidases } & $\begin{array}{l}\text { Marine sediments: surface of daily inundate saline mud flats (Paesens-Moddergat, } \\
\text { Netherlands) }\end{array}$ & Functional & Gabor et al., 2004b \\
\hline & Loamy soil and marine sludges (with/without enrichment) & Functional & Gabor et al., 2004b \\
\hline Carboxypeptidases & Pest corn earworm insect gut (Helicoverpa armigera) & PCR & Bown et al., 2004 \\
\hline Nitrile hydratase & Terrestrial and aquatic habitats (not specified) & Functional & Liebeton and Eck, 2004 \\
\hline $\begin{array}{l}\text { Proteorhodopsin-type } \\
\text { protein gene }\end{array}$ & Monterrey Bay and Mediterranean and Red Sea & Shot gun & $\begin{array}{l}\text { Sabehi et al., 2003; } \\
\text { Beja, } 2004\end{array}$ \\
\hline \multirow[t]{2}{*}{ Antibiotic resistance genes } & Human dental plaque and saliva & PCR & Díaz-Torres et al., 2003 \\
\hline & Arable field & PCR & Courtois et al., 2003 \\
\hline
\end{tabular}


nases, 1,4- $\alpha$-glucan branching enzymes), oxidoreductases, dehydrogenases, polyphenol oxidases and oxygenases (see table 2 and references therein). For example, from $1,267,000$ independent clones derived from complex microbial consortia of different soils, 24 new genes specifying the formation of carbonyls from short-chain polyols were found. The sequences of three translated gene products revealed no significant similarities to known alcohol oxidoreductases, although they contained putative glycine-rich regions characteristic of nicotinamide cofactor binding sites [Knietsch et al., 2003a-c]. Two highly enantioselective esterases belonging to the lipase/esterase family VIII, one of which lacked the mandatory lipase/esterase motif, were retrieved from a metagenome library obtained from a drinking water biofilm [Elend et al., 2006]. The novelty of enzymes retrieved from metagenome libraries was emphasized by the recent report of Lämmle et al. [2007] in which 51 enzymes, including lipolytic enzymes, amylases, phosphatases and dioxygenases, retrieved from soil metagenomes are described which are new and only weakly related to known enzymes. A similar finding was obtained by high-throughput screening of multiple environmental DNA libraries which resulted in the identification of more than 40 new microbial pectate lyases. Several of these exhibited activity optima at extreme $\mathrm{pH}$ values and high specific activities on pectic material in cotton fibers, which will favor their use in the scouring process [Solback et al., 2005]. Further improvement of thermostability by protein evolution resulted in one such enzyme exhibiting superior scouring results, which may open a route to replacement of the conventional and environmentally harmful chemical scouring process in the textile industry.

Apart from traditional enzymatic screens involving detection of product from offered substrate, a number of other interesting functional screens have been reported. A very simple screening strategy is based on the ability of DNA fragments encoding certain enzymes to confer new carbon utilization phenotypes on the host, which allows direct selection of positive clones on media containing the appropriate carbon source. Examples include the retrieval from oil-contaminated soil of new naphthalene dioxygenases (NDOs), the first enzymes of pathways for the aerobic catabolism of naphthalene and polyaromatic hydrocarbons, and which catalyze the dioxygenation activation of the first aromatic ring to be dismantled [Ono et al., 2006]. In this case, the cosmidbased metagenome clones were introduced into $P$. putida KTSK2 or G7K2 host bacteria, which become able to use naphthalene as a sole carbon source when they acquire and express $n d o$ genes. A similar approach was used to retrieve from a Black Sea methanotrophic microbial mat a catabolic gene cluster, that included genes for a benzoyl-CoA reductase, a ketoacid:acceptor oxidoreductase and a ferredoxin, for the anaerobic degradation of benzoate [Kube et al., 2005]. This approach is particularly useful for the retrieval of environmental genes encoding enzymes and enzyme suites that can be useful for the degradation/transformation of organic/inorganic environmental pollutants and that have bioremediation/mitigation potential.

\section{Genetic Traps}

The identification of genes specifying the synthesis of compounds that induce the expression of a reporter under the control of a quorum-sensing promoter, i.e. $g f p$ downstream of a luxR promoter [Handelsman, 2004] represents the issue totally different from standard activity screening. In this case, the host used for the metagenome library contains the screen construct and, if an inducer of the $l u x R$-mediated transcription of $g f p$ is expressed from a cloned metagenomic DNA fragment, the cells fluoresce and can be captured by fluorescence-activated or inactivated cell sorting or as colonies observed by fluorescence microscopy [Williamson et al., 2005]. In the case reported, 53,000 clones from eight metagenomic libraries were screened and eleven clones that induce or inhibit expression of GFP were identified. These had more than $62 \%$ amino acid sequence identity to their closest matches in GenBank but similar functionalities to homologous proteins. This subsequently led to the development of new genetic traps based on transcriptional regulators and it is to be expected that such traps will gain in importance in the prospecting of metagenome libraries [e.g. Galvao et al., 2005; Mohn et al., 2006].

An elegant screen for metagenome DNA fragments that affect $E$. coli mutational pathways were recently described, based on the fact that DNA sequence repeats found in some of the metagenomic clones cause general genome instability when present in multiple copies, and generate elevated levels of blue papillae in host E. coli colonies. This resulted in the isolation of 26 metagenomic clones from a soil microbial community that encode new RNA methyltransferases, bacterial microcompartment proteins, calcium binding hemolysin proteins, sigma factors, etc. [Yang et al., 2006].

\section{High-Throughput Approaches}

A wide range of fast, efficient and high-throughput screening methods and assays have been established in 
recent years, and continue to develop in step with new developments in robotics, high-throughput analytical instrumentation, and functional assays. For example, fluorescence-activated cell sorting (FACS), a technology that enables the identification of biological activity within a single cell, has great potential for high-throughput screening of metagenome libraries [Podar et al., 2007]. One system developed by Diversa Corp. (San Diego, Calif., USA) incorporates a laser with multiple wavelength capabilities and the ability to screen up to 50,000 clones per second, or over 1 billion clones per day.

\section{Metagenomes as Resources for Bioactive Compounds}

One of the many challenges of the 21st century is the emergence of new infectious agents and spread of multidrug-resistant pathogens, both of which can be resistant to currently available drugs [Bode and Müller, 2005; Courtois et al., 2003; Piel et al., 2005; Wang, 2006]. There is an urgent need for new drugs. Microbial natural products have traditionally constituted an excellent source of drug leads, so metagenomics holds great promise for discovering new natural products/drug leads. However, since natural products are generally chemically complex secondary metabolites, whose biosynthesis involves multistep metabolic pathways, their expression in a surrogate requires relatively large insert libraries and a host providing required ancillary metabolic reactions. However, the prospect of being able not only to harvest new natural products by metagenomics, but also creating new ones by metagenome-driven combinatorial genetics, represents an exciting technical challenge.

Because it is generally accepted that marine microbial communities account for more than $80 \%$ of life on earth, and have an indispensable role in primary energy and carbon recycling, marine chemodiversity is considered to be the major target for the prospecting for new natural products that can become drug leads. At first sight it is therefore surprising that the number of commercially available drugs originating from marine sources falls far behind those derived from culturable soil organisms, which provide $60 \%$ of the antibiotics in the pharmaceutical industry. However, most marine microorganisms that produce bioactive compounds cannot be cultivated using traditionally employed cultural conditions, despite recent progress in cultivation technology, and for the few that can be cultured, the culturing methodology is laborious. Sponges are considered to be an important marine source of biologically active natural products, though the true origin of such compounds is in many cases suspected to be their microbial symbionts. New natural products from microbial symbionts of sponges Theonella swinhoei, Pseudoceratina clavata and Discodermia dissolute included the novel antitumor polyketides [Kim and Fuerst, 2006; Piel et al., 2004; Schirmer et al., 2005].

\section{Need for Multiple Hosts}

Although E. coli $\mathrm{K}-12$ has been, and will continue to be, the gene cloning workhorse and surrogate of choice for most applications, the diversity of gene expression signals and systems in the microbial world, the range of GC content, the diversity of RNA metabolic systems and protein folding, degradation and secretion systems, etc., all conspire to prevent functional expression of a significant fraction of environmental genes and gene suites in E. coli [e.g. see Gabor et al., 2004a]. For this reason, additional hosts like Bacillus subtilis, Pseudomonas putida, Bacillus sp. (Firmicutes), Streptomyces lividans (Actinobacteria) and Rhizobium leguminosarum (Alphaproteobacteria), that provide different gene expression backgrounds, have been developed [e.g. see Lorenz and Eck, 2005]. It is important to note that this does not mean that $E$. coli is thereby replaced, since the fraction of environmental genes expressed in these alternate hosts may be no better than that in E. coli, but rather that different spectra of expressed genes can now be sampled. In other words, E. coli will generally continue to be used as the primary surrogate to create the initial libraries, but that these may subsequently be transferred into additional surrogates to expand the range of expressed genes. For example, in the case of a metagenome of a wastewater treatment anaerobic digestor, it was reported that some atypical alcohol/ aldehyde dehydrogenases were functionally expressed in a $R$. leguminosarum host but not in E. coli [Wexler et al., 2005].

The problem of expression of heterologous genes becomes more acute in the case of multiple genes required for the synthesis of secondary metabolites, or for combinatorial genetics, where particular accessory metabolic functions are a prerequisite, since both involve (re)constitution of complex biosynthetic pathways involving functional expression of large multienzyme assemblies [Wenzel and Müller, 2005]. For this, appropriately tailored broad host range and shuttle vectors, able to replicate in diverse hosts that are good secondary me- 
tabolite producers, are needed. Though some useful host: vector systems of this type are already available, others that will require extensive engineering are urgently needed. However, current efforts to create new and improve existing systems will provide in the rather near future a broad choice of options for large-scale metagenome library screening.

\section{Strategies for Biomass-Poor Samples}

Some microbiologically interesting habitats, particularly those at the biosphere-lithosphere interface and highly polluted environments, which are physicochemically extreme and thus hostile to life, contain very few microbes (e.g. the deep hypersaline anoxic basins of the Mediterranean Sea: van der Wielen, et al. [2005]; Daffonchio et al. [2006]; Hallsworth et al. [2007], and heavy metal- and nitrate-contaminated soils: Abulencia et al. [2006]). Though the genetic diversity of such environments may in some cases be low, it may nevertheless be particularly interesting, so attracts special efforts to access it. One possible solution is to amplify the available biomass by enrichment [e.g. Ferrer et al., 2005], but this inevitably results in some loss of biodiversity and thus to biases in the libraries. An alternate solution is to amplify the genomic DNA extracted from the small amount of biomass obtained. Multiple displacement amplification (MDA), by means of $\Phi 29$ DNA polymerase, has been applied to amplify whole genomes from contaminated and subsurface sediments [Abulencia et al., 2006], Eastern Snake River plain aquifer [Erwin et al., 2005] and scleractinian coral [Yokouchi et al., 2006]. This approach currently suffers from several problems - the creation of chimeric sequences, amplification biases, and small amplification products - but still has utility to generate sufficient material for library construction from samples with extremely low DNA yields. More importantly, it should encourage renewed efforts to develop better whole (meta)genome amplification (WGA) procedures. Indeed, recent successful examples of MDA-driven whole genome amplification from single cells obtained from environmental probes [Spits et al., 2006; Stepanauskas and Sieracki, 2007] suggest WGA would not only provide access to the biodiversity of biomass-poor environments, but also extend options for automation and high-throughput practices in library construction and screening.

\section{Gene Origin}

As indicated above, the isolation of a novel gene/enzyme/activity generally automatically provokes the question of its origin, since its biological role and significance are important issues in biodiversity, and the possibility of further novel functions awaiting discovery in the particular organism is intriguing. The importance of this has in the past led to some experimental designs that deliberately restricted metagenome prospecting to genomic regions containing $16 \mathrm{~S} / 18 \mathrm{~S}$ rRNA and other phylogenetic marker genes (e.g. gyrB, $r p o \mathrm{~B}$, etc.) which are common subjects of the multilocus sequencing technique and which immediately provide the taxonomic affiliation of the accompanying genes. This approach, however, is obviously incompatible with a goal of accessing the broadest possible diversity for gene mining, since these marker genes are often not amenable to the PCR due to their diversity and since the vast majority of every genome is thereby discarded from the screening.

Two approaches are currently in use to obtain taxonomic affiliations of the organisms from which a DNA of interest originated. One is to extract taxonomic information from the DNA fragment in the library clone. In silico assessment of tetranucleotide usage patterns has been proposed as a useful approach to obtain taxonomic information [Teeling et al., 2004]. The quality of the taxonomic information thereby obtained is determined by the amount of sequence information available - a minimum of $5 \mathrm{~kb}$ of sequence is required, but $10-20 \mathrm{~kb}$ is needed for greater confidence - so some small inserts in expression libraries cannot be analyzed satisfactorily by this method. Alternatively, if the microbial community of the sample is not too complex, mega-sequencing of the environmental DNA may yield fragment overlaps that identify contiguous genomic fragments and reveal signatures of $16 \mathrm{~S} / 18 \mathrm{~S}$ (or other marker genes) on one of these, so that a taxonomic affiliation is obtained. Again, this can rarely be achieved with genes from small insert expression libraries, hence the reason to create large insert archive libraries as a reference for expression libraries.

\section{Concluding Remarks}

A principal strategy to obtain enzymes with desired properties for industrial processes traditionally involves the optimization of available enzymes. However, despite the increasing sophistication of the optimization methods, including random mutagenesis, domain shuffling, 
combinatorial genetics, etc., and the availability of highquality structural information, enabling precise knowledge-based protein design, the structural and functional space that can be thereby explored is rather limited. Recent studies on enzyme diversity that can be accessed through metagenomics suggests that not only is the structural and functional space of recently accessed enzymes far greater than that previously known from enzymes of cultivated microbes, but that we have so far only explored a tiny part of the actual diversity space. This suggests that it will be far more efficient and productive to seek new enzymes from metagenome libraries than to tweak the activities of existing ones. Of course, further optimization of newly discovered enzymes can always then be extended by the powerful methods of combinatorial genetics.

We started out by stating that the grand challenge of metagenomics is to access and exploit the enormous biodiversity of the microbial world. This absolutely requires establishment of substantial integrated research consortia with complementary scientific experiences in microbial genetics/genomics, bioinformatics, microbial ecophysiology, enzymology, analytical and synthetic chemistry and bioengineering, and strong interfacing with end-users in industry, medicine, agriculture, etc. Two major bottlenecks to progress are the paucity of good enzymologists and high-quality enzymological analysis of the rapidly expanding number of new enzymes being discovered from the metagenome libraries, and the large number of unvalidated annotations in current databases, many of which are wrong and which perpetuate incorrect annotations that have many knock-on effects (in bioinformatics, metabolic network construction and metabolic design, systems and synthetic biology, etc.), and that cannot be corrected without experimental validation. Databases are only as useful as the quality of the data they contain; bioinformatics is only as good as the information fed into the computer. If we ignore this problem, we waste increasingly significant effort and financial resources.

Finally, though the emphasis of this review is discovery of new enzymes and other biological products and activities from metagenomes for applications, particularly in sustainable industrial processes (green chemistry, renewable resources, energy conservation), agriculture and medicine, the now demonstrated richness of very new molecules waiting to be discovered will clearly bring new biological knowledge about underlying mechanisms that will have at least as great an impact as the new applications.

\section{Acknowledgments}

This research was supported by German, Spanish and European Community Projects MetaGenoMik, 200680I126, BIO200611738, EVK3-2000-00042 'BIODEEP', EVK3-2002-00077 'COMMODE' and MERG-CT-2004-505242 'BIOMELI'. It was also supported by the Spanish MEC BIO2006-11738 and CSD2007-00005 project. A.B. and M.F. thank the Spanish Ministerio de Ciencia y Tecnología for a FPU fellowship. K.N.T. expresses gratitude to the Fonds der Chemischen Industrie for generous support.

\section{References}

- Abulencia CR, Wyborski DL, García JA, Podar M, Chen W, Chang SH, Chanf HW, Watson D, Brodie EL, Hazen TC, Keller M: Environmental whole-genome amplification to access microbial populations in contaminated sediments. Appl Environ Microbiol 2006;72: 3291-3301.

Alcalde M, Ferrer M, Plou FJ, Ballesteros A: Environmental biocatalysis: from remediation with enzymes to novel green processes. Trends Biotechnol 2006;24:281-287.

Angly FE, Felts B, Breitbart M, Salamon P, Edwards RA, Carlson C, Chan AM, Haynes M, Kelley S, Liu H, Mahaffy JM, Mueller JE, Nulton J, Olson R, Parsons R, Rayhawk S, Suttle CA, Rohwer F: The marine viromes of four oceanic regions. PLoS Biol 2006;4:21212131.

Metagenomics for Mining New Genetic

Resources of Microbial Communities
Angly FE, Rodríguez-Brito B, Bangor D, McNairnie P, Breitbart M, Salamon P, Felts B, Nulton J, Mahaffy J, Rohwer F: PHACCS, an online tool for estimating the structure and diversity of uncultured viral communities using metagenomic information. BMC Bioinformatics 2005;6:41-50.

Béjà O: To BAC or not to BAC: marine ecogenomics. Curr Opin Biotechnol 2004;15:187190.

- Beloqui A, Pita M, Polaina J, Martinez-Arias A, Golyshina OV, Zumarraga M, Yakimov MM, Garcia-Arellano H, Alcalde M, Fernandez VM, Elborough K, Andreu JM, Ballesteros A, Plou FJ, Timmis KN, Ferrer M, Golyshin PN: Novel polyphenol oxidase mined from a metagenome expression library of bovine rumen: biochemical properties, structural analysis and phylogenetic relationships. J Biol Chem 2006;281:22933-22942.
Bertrand H, Poly F, Van VT, Lombard N, Nalin R, Vogel TM, Simonet P: High molecular weight DNA recovery from soils prerequisite for biotechnological metagenomic library construction. J Microbiol Methods 2005;62: 1-11.

- Bode HB, Müller R: The impact of bacterial genomics on natural product research. Angew Chem Int Ed Engl 2005;44:6828-6846.

Bown DP, Gatehouse JA: Characterization of a digestive carboxypeptidase from the insect pest corn earworm (Helicoverpa armigera) with novel specificity towards C-terminal glutamate residues. Eur J Biochem 2004;271: 2000-2011.

Breitbart M, Felts B, Kelley S, Mahaffy JM, Bulton J, Salamon P, Rohwer F: Diversity and population structure of a near-shore marine-sediment viral community. Proc Biol Sci 2004;271:565-574. 
Breitbart M, Rohwer F: Here a virus, there is a virus, everywhere the same virus? Trend Microbiol 2005; 13:278-284.

-Brennan Y, Callen WN, Christoffersen L, Dupree $\mathrm{P}$, Goubet F, Healey S, Hernández M, Keller M, Li K, Palackal N, Sittenfeld A, Tamayo G, Wells S, Hazlewood GP, Mathur EJ, Short JM, Robertson DE, Steer BA: Unusual microbial xylanases from insect guts. Appl Environ Microbiol 2004;70:36093617.

-Byun JS, Rhee JK, Kim DU, Oh JW, Cho HS: Crystallization and preliminary X-ray crystallographic analysis of EstE1, a new and thermostable esterase cloned from a metagenomic library. Acta Crystallograph Sect F Struct Biol Cryst Commun 2006;62:145147.

Chen ZW, Liu YY, Wu JF, She Q, Jiang CY, Liu SJ: Novel bacterial sulphur oxygenase reductases from bioreactors treating gold-bearing concentrates. Appl Microbiol Biotechnol 2007;74:688-698.

-Cole JR, Chai B, Marsh TL, Farris RJ, Wang Q, Kulam SA, Chandra S, McGarrell DM, Schmidt TM, Garrity GM, Tiedje JM: The ribosomal database project (RDP-II): previewing a new autoaligner that allows regular updates and the new prokaryotic taxonomy. Nucleic Acids Res 2003;31:442-443.

-Cottrell MT, Moore JA, Kirchman DL: Chitinases from uncultured marine microorganisms. Appl Environ Microbiol 1999;65:25532557.

-Cottrell MT, Waidner LA, Yu LY, Kirchman DL: Bacterial diversity of metagenomic and PCR libraries from the Delaware River. Environ Microbiol 2005a;7:1883-1895.

Cottrell MT, Yu L, Kirchman DL: Sequence and expression analyses of Cytophaga-like hydrolases in a Western Arctic metagenomic library and the Sargasso Sea. Appl Environ Microbiol 2005b;71:8506-8513.

-Courtois S, Cappellano CM, Ball M, Francou FX, Normand P, Helynck G, Martinez A, Kolvek SJ, Hopke J, Osburne MS, August PR, Nalin R, Guérineau M, Jeannin P, Simonet P, Pernodet JL: Recombinant environmental libraries provide access to microbial diversity for drug discovery from natural products. Appl Environ Microbiol 2003;69:49-55.

-Cowan D, Meyer Q, Stafford W, Muyanga S, Cameron R, Wittwer P: Metagenomic gene discovery: past, present and future. Trends Biotechnol 2005;23:321-329.

-Culley AI, Lang AS, Suttle CA: Metagenomic analysis of coastal RNA virus communities. Science 2006;312:1795-1798.

Curtis TP, Sloan WT, Scannell SW: Estimating prokaryotic diversity and its limits. Proc Natl Acad Sci USA 2001;43:52-68.
Daffonchio D, Borin S, Brusa T, Brusetti L, van der Wielen PW, Bolhuis H, Yakimov MM, D’Auria G, Giuliano L, Marty D, Tamburini C, McGenity TJ, Hallsworth JE, Sass AM, Timmis KN, Tselepides A, de Lange GJ, Hubner A, Thomson J, Varnavas SP, Gasparoni F, Gerber HW, Malinverno E, Corselli C, Garcin J, McKew B, Golyshin PN, Lampadariou N, Polymenakou P, Calore D, Cenedese S, Zanon F, Hoog S; Biodeep Scientific Party: Prokaryote stratification along a three meter halocline in an Eastern Mediterranean deep. Nature, 2006;440:203-207.

DeLong EF: Microbial community genomics in the ocean. Nat Rev Microbiol 2005;3:459469.

Deutschbauer AM, Chivian D, Arkin AP: Genomics for environmental microbiology. Curr Opin Biotechnol 2006;17:229-235.

-Díaz-Torres ML, McNab R, Spratt DA, Villedieu A, Hunt N, Wilson M, Mullany P: Novel tetracycline resistance determinant from the oral metagenome. Antimicrob Agents Chemother 2003;47:1430-1432.

Dumont MG, Radajewski SM, Miguez CB, McDonald IR, Murrel JC: Identification of a complete methane monooxygenase operon from soil by combining stable isotope probing and metagenomic analysis. Environ Microbiol 2006;8:1240-1250.

Edwards RA, Rohwer F: Viral metagenomics. Nat Rev Microbiol 2005;3:504-510.

-Elend C, Schmeisser C, Leggewie C, Babiak P, Carballeira JD, Steele HL, Reymond JL, Jaeger KE, Streit WR: Isolation and biochemical characterization of two novel metagenomederived esterases. Appl Environ Microbiol 2006;72:3637-3645.

Elshahed MS, Najar FZ, Aycock M, Qu Chunmei, Roe BA, Krumholz LR: Metagenomic analysis of the microbial community of zodletone spring (Oklahoma): insights into the genome of a member of the novel candidate division OD1. Appl Environ Microbiol 2005; 71:7598-7602.

Erwin DP, Erickson IK, Delwiche ME, Colwell FS, Strap JL, Crawford RL: Diversity of oxygenase genes from methane- and ammoniaoxidizing bacteria in the Eastern Snake River Plain aquifer. Appl Environ Microbiol 2005; 71:2016-2025.

- Ferrer M, Golyshina OV, Chernikova TN, Khachane AN, Martins Dos Santos VA, Yakimov MM, Timmis KN, Golyshin PN: Novel microbial enzymes mined from the Urania deep-sea hypersaline anoxic basin. Chem Biol 2005a;12:895-904.

- Ferrer M, Golyshina OV, Chernikova TN, Khachane AN, Reyes-Duarte D, Santos VA, Strompl C, Elborough K, Jarvis G, Neef A, Yakimov MM, Timmis KN, Golyshin PN: Novel hydrolase diversity retrieved from a metagenome library of bovine rumen microflora. Environ Microbiol 2005b;7:19962010.
Fitches E, Wilkinson H, Bell H, Bown DP, Gatehouse JA, Edwards JP: Cloning, expression and functional characterisation of chitinase from larvae of tomato moth (Lacanobia oleracea): a demonstration of the insecticidal activity of insect chitinase. Insect Biochem Mol Biol 2004;34:1037-1050.

Francis CA, Roberts KJ, Beman JM, Santoro AE, Oakley BB: Ubiquity and diversity of ammonia-oxidizing archaea in water columns and sediments of the ocean. Proc Natl Acad Sci USA 2005; 102:14683-14688.

Gabor EM, de Vieres EJ, Janssen DB: Quantifying the accessibility of the metagenome by random expression cloning techniques. Environ Microbiol 2004a;6:879-886.

Gabor EM, de Vieres EJ, Janssen DB: Construction, characterization, and use of small-insert gene banks of DNA isolated from soil and enrichment cultures for the recovery of novel amidases. Environ Microbiol 2004b;6: 948-958.

Galvao T, Mohn W, de Lorenzo V: Exploring the microbial biodegradation and biotransformation gene pool. Trends Biotechnol 2005; 23:497-506.

Galbraith EA, Antonopoulos DA, White BA: Suppressive subtractive hybridization as a tool for identifying genetic diversity in an environmental metagenome: the rumen as a model. Environ Microbiol 2004;6:928-937.

Gill SR, Pop M, Deboy RT, Eckburg PB, Turnbaugh PJ, Samuel BS, Gordon JI, Relman DA, Fraser-Liggett CM, Nelson KE: Metagenomic analysis of the human distal gut microbiome. Science 2006;312:1355-1359.

- Grant S, Gant WD, Cowan DA, Jones BE, Ma Y, Ventosa A, Heaphy S: Identification of eukaryotic open reading frames in metagenomic cDNA libraries made from environmental samples. Appl Environ Microbiol 2006;72:135-143.

Green BD, Keller M: Capturing the uncultivated majority. Curr Opin Biotechnol 12006;7: 236-240.

Gros R, Jocteur Monrozier L, Faivre P: Does disturbance and restoration of alpine grassland soils affect the genetic structure and diversity of bacterial and $\mathrm{N}_{2}$-fixing populations? Environ Microbiol 2006;8:1889-1901.

Hallsworth JE, Yakimov MM, Golyshin PN, Gillion JL, D'Auria G, Alves, La Cono V, McKew BA, Harris G, Giuliano L, Timmis KN, McGenity TJ: Limits of life in $\mathrm{MgCl}_{2}$-containing environments: chaotropicity rules. Environ Microbiol 2007;9:801-813.

-Handelsman J: Metagenomics: applications of genomics to uncultured microorganisms. Microbiol Mol Biol Rev 2004;68:669-685.

Hayashi H, Abe T, Sakarnoto M, Ohara H, Ikernura T, Sakka K, Benno Y: Direct cloning of genes encoding novel xylanases from the human gut. Can J Microbiol 2005;51:251-259. 
-He Z, Xiao S, Xie X, Zhong H, Hu Y, Li Q, Gao F, Kube M, Beck A, Meyerdierks A, Amann R, Li G, Liu J, Qiu G: Molecular diversity of microbial community in acid mine drainages of Yunfu sulfide mine. Extremophiles 2007;11: 305-314.

-Holmes AJ, Gillings MR, Nield BS, Mabbutt BC, Nevalainen KMH, Stokes HW: The gene cassette metagenome is a basic resource for bacterial genome evolution. Environ Microbiol 2003;5:383-394.

-Johnson AWB, Li Y, Ogilvie L: Metagenomic marine nitrogen fixation - feast of famine? Trend Microbiol 2005;13:416-419.

Johnson PL, Slatkin M: Inference of population genetic parameters in metagenomics: a clean look at messy data. Genome Res 2006; 16: $1320-1327$.

Jones BV, Marchesi JR: Transposon-aided capture (TRACA) of plasmids resident in the human gut mobile metagenome. Nat Methods 2007;4:55-61.

-Kalyuzhnaya MG, Nercessian O, Lapidus A, Chistoserdova L: Fishing for biodiversity: novel methanopterin-linked $C_{1}$ transfer genes deduced from the Sargasso Sea metagenome. Environ Microbiol 2005;7:19091916.

Kim TK, Fuerst JA: Diversity of polyketide synthase genes from bacteria associated with the marine sponge Pseudoceratina clavata: culture-dependent and culture-independent approaches. Environ Microbiol 2006; 8: 1460-1470.

- Kim YJ, Choi GS, Kim SB, Yoon GS, Kim YS, Ryu YW: Screening and characterization of a novel esterase from a metagenomic library. Protein Expr Purif 2006;45:315-323.

Klappenbach JA, Dunbar JM and Schmidt TM: rRNA operon copy number reflects ecological strategies of bacteria. Appl Environ Microbiol 2000;66:1328-1333.

Knietsch A, Bowien S, Whited G, Gottschalk G, Daniel R: Identification and characterization of coenzyme $\mathrm{B}_{12}$-dependent glycerol dehydratase- and diol dehydratase-encoding genes from metagenomic DNA libraries derived from enrichment cultures. Appl Environ Microbiol 2003a;69:3048-3060.

-Knietsch A, Waschkowitz T, Bowien S, Henne A, Daniel R: Construction and screening of metagenomic libraries derived from enrichment cultures: generation of a gene bank for genes conferring alcohol oxidoreductase activity on Escherichia coli. Appl Environ Microbiol 2003b;69:1408-1416.

Knietsch A, Waschkowitz T, Bowien S, Henne A, Daniel R: Metagenomes of complex microbial consortia derived from different soils as sources for novel genes conferring formation of carbonyls from short-chain polyols on Escherichia coli. J Mol Microbiol Biotechnol 2003c;5:46-56. Reinhardt R, Rabus R: A catabolic gene cluster for anaerobic benzoate degradation in a methanotrophic microbial Black Sea mats. Syst Appl Microbiol 2005;28:287-294.

ämmle K, Zipper H, Breuer M, Hauer B, Buta C, Brunner H, Rupp S: Identification of novel enzymes with different hydrolytic activities by metagenome expression cloning. J Biotechnol 2007; 127:575-592.

LeCleir GR, Buchan A, Hollibaugh T: Chitinase gene sequences retrieved from diverse aquatic habitats reveal environment-specific distributions. Appl Environ Microbiol 2004;70: 6977-6983.

Lee MH, Lee CH, Oh TK, Song JK, Yoon JH: Isolation and characterization of a novel lipase from a metagenomic library of tidal flat sediments: evidence for a new family of bacteriallipases. Appl Environ Microbiol 2006;72: 7406-7409.

Lee SW, Won K, Lim HK, Kim JC, Choi GJ, Cho KY: Screening for novel lipolytic enzymes from uncultured soil microorganisms. App Microbiol Biotechnol 2004;65:720-726.

Legault BA, López-López A., Alba-Casado JC, Doolittle WF, Bolhuis H, Rodríguez-Valera F, Papke RT: Environmental genomics of 'Haloquadratum walsbyi' in a saltern crystallizer indicates a large pool of accessory genes in an otherwise coherent species. BMC Genomics 2006;7:171-184.

Liebeton K, Eck J, Identification and expression in E. coli of novel nitrile hydratases from the metagenome. Life Sci 2004;4:557-562.

Liles MR, Manske BF, Bintrim SB, Handelsman J, Goodman RM: A census of rRNA genes and linked genomic sequences within a soil metagenomic library. Appl Environ Microbiol 2003;69:2684-2691.

Lim KH, Chung EJ, Kim JC, Choi GJ, Jang KS, Chung YR, Cho KY, Lee SW: Characterization of a forest soil metagenome clone that confers indirubin and indigo production on Escherichia coli. Appl Environ Microbiol 2005;71:7768-7777.

Lorenz P, Eck J: Metagenomics and industrial applications. Nat Rev Microbiol 2005;3:510516.

Manichanh C, Rigottier-Gois L, Bonnaud E, Gloux K, Pelletier E, Frangeul L, Nalin R, Jarrin C, Chardon P, Marteau P, Roca J, Dore $\mathrm{J}$ : Reduced diversity of faecal microbiota in Crohn's disease revealed by a metagenomic approach. Gut 2006;55:205-211.

Meyer QC, Burton SG, Cowan DA: Subtractive hybridization magnetic bead capture: a new technique for the recovery of full-length ORFs from the metagenome. Biotechnol J 2007;2:36-40.

Mohn WW, Garmendia J, Galvao TC, De Lorenzo V: Surveying biotransformations with à la carte genetic traps: translating dehydrochlorination of lindane ( $\gamma$-hexachlorocyclohexane) into lacZ-based phenotypes. Environ Microbiol 2006;8:546-55.
Moreira D, Rodríguez-Valera F, López-García P: Analysis of a genome fragment of a deep-sea uncultivated group II euryarchaeote containing $16 \mathrm{~S}$ rDNA, a spectomycin-like operon and several energy metabolism genes. Environ Microbiol 2004;6:959-969.

- Moreira D, Rodríguez-Valera F, López-García P: Metagenomic analysis of mesopelagic Antarctic plankton reveals a novel deltaproteobacterial group. Microbiology 2006; 152: 505-517.

Noguchi H, Park J, Tagaki T: Metagene: prokaryotic gene finding from environmental genome shotgun sequences. Nucleic Acids Res 2006;34:5623-5630.

Noonan JP, Hofreiter M, Smith D, Priest JR, Rohland N, Rabeder G, Krause J, Detter JC, Paabo S, Rubin EM: Genomic sequencing of Pleistocene cave bears. Science 2005;309: 597-599.

Nunoura T, Hirayama H, Takami H, Olda H, Nishi S, Shimamura S, Suzuki Y, Inagaki F, Takai K, Nealson KH, Hirikoshi K: Genetic and functional properties of uncultivated thermophilic crenarchaeotes from a subsurface gold mine as revealed by analysis of genome fragments. Environ Microbiol 2005;7: 1967-1984.

Ono A, Miyazaki R, Ohtsubo Y, Nagata Y, Tsuda $\mathrm{M}$ : Isolation and characterization of naphthalene-catabolic genes and plasmids from oil-contaminated soil by using two cultivation-independent approaches. Appl Microbiol Biotechnol 2007;74:501-510.

- Pace NR: A molecular view of microbial diversity and the biosphere. Science 1997;276: 734-740.

Park HJ, Jeon JH, Kang SG, Lee JH, Lee SA, Kim HK: Functional expression and refolding of a new alkaline esterase, EM28L8 from deepsea sediment meagenome. Protein Expr Purif 2007;52:340-347.

Paul D, Pandey G, Meier C, van der Meer JR, Jain RK: Bacterial community structure of a pesticide-contaminated site and assessment of changes induced in community-structure during bioremediation. FEMS Microbiol Ecol 2006;57:116-127.

- Piel J, Butzke D, Fusetani N, Hui D, Platzer M, Wen G, Matsunaga S: Exploring the chemistry of uncultivated bacterial symbionts: antitumor polyketides of the pederin family. J Nat Prod 2005;68:472-479.

-Piel J, Hui D, Wen G, Butzke D, Platzer M, Fusetani N, Matsunaga S: Antitumor poliketide biosynthesis by an uncultivated bacterial symbiont of the marine sponge Theonella swinhoei. Proc Natl Acad Sci USA 2004;16: 16222-16227.

- Podar M, Abulencia CB, Walcher M, Hutchison D, Zengler K, Garcia JA, Holland T, Cotton D, Hauser L, Keller M: Targeted access to the genomes of low-abundance organisms in complex microbial communities. Appl Environ Microbiol 2007;73:3205-3214. 
-Ranjan R, Grover A, Kapardar RK, Sharma R: Isolation of novel lipolytic genes from uncultured bacteria of pond water. Biochem Biophys Res Commun 2005;335:57-65.

Rees HC, Grant S, Jones B, Grant WD, Heaphy S: Detecting cellulase and esterase enzyme activities encoded by novel genes present in environmental DNA libraries. Extremophiles 2003;7:415-421.

Reyes-Duarte D, Polaina J, Lopez-Cortes N, Alcalde M, Plou FJ, Elborough K, Ballesteros A, Timmis KN, Golyshin PN, Ferrer M: Conversion of a carboxylesterase into a triacylglycerol lipase by a random mutation. Angew Chem Int Ed Engl 2005;44:7553-7557.

Rhee JK, Ahn DG, Kim YG, Oh JW: New thermophilic and thermostable esterase with sequence similarity to the hormone-sensitive lipase family, cloned from a metagenomic library. Appl Environ Microbiol 2005;71:817825.

Ricke P, Kube M, Nakagawa S, Erkel C, Reinhardt R, Liesack W: First genome data from uncultured upland soil cluster alpha methanotrophs provide further evidence for a close phylogenetic relationship to Methylocapsa acidiphila $\mathrm{B}_{2}$ and for high-affinity methanotrophy involving particulate methane monooxygenase. Appl Environ Microbiol 2005;71:7472-7482.

-Riesenfeld CS, Schloss PD, Handelsman J: Metagenomics, genomic analysis of microbial communities. Annu Rev Genet 2004;38: 525-552.

-Rodríguez-Brito B, Rohwer F, Edwards RA: An application of statistics to comparative metagenomics. BMC Bioinformatics 2006; 7 : 162-173.

Rusch DB, Halpern AL, Sutton G, Heidelberg $\mathrm{KB}$, Williamson S, Yooseph S, Wu D, Eisen JA, Hoffman JM, Remington K, Beeson K, Tran B, Smith H, Baden-Tillson H, Stewart C, Thorpe J, Freeman J, Andrews-Pfannkoch C, Venter JE, Li K, Kravitz S, Heidelberg JF, Utterback T, Rogers YH, Falcon LI, Souza V, Bonilla-Rosso G, Eguiarte LE, Karl DM, Sathyendranath S, Platt T, Bermingham E, Gallardo V, Tamayo-Castillo G, Ferrari MR, Strausberg RL, Nealson K, Friedman R, Frazier M, Venter JC: The Sorcerer II Global Ocean Sampling Expedition: Northwest Atlantic through Eastern Tropical Pacific. PLoS Biol 2007;5:e77.

-Sabehi G, Massana R, Bielawski JP, Rosenberg M, DeLong EF, Béjà O: Novel proteorhodopsin variants from the Mediterranean and Red Seas. Environ Microbiol 2003;5:842849.

-Schirmer A, Gadkari R, Reeves CD, Ibrahim F, DeLong EF, Hutchinson CR: Metagenomic analysis reveals diverse polyketide synthase gene clusters in microorganisms associated with the marine sponge Discodermia dissolute. Appl Environ Microbiol 2005;71:48404849.
Schmeisser C, Stöckigt C, Raasch C, Windender J, Timmis KN, Wenderoth DF, Flemming HC, Liesegang H, Schmitz RA, Jaeger KE, Steit WR: Metagenome survey of biofilms in drinking-water networks. Appl Environ Microbiol 2003;69:7298-73069.

Schmid A, Dordick JS, Hauer B, Kiener A, Wubbolts $\mathrm{M}$, Witholt $\mathrm{B}$ : Industrial biocatalysis today and tomorrow. Nature 2001;409:258268.

Sebat JL, Colwell FS, Crawford RL: Metagenomic profiling: Microarray analysis of an environmental genomic library. Appl Environ Microbiol 2003;69:4927-4934.

-Seong JS, Jeon JH, Lee JH, Jeong SH, Jeong BC, Kim SJ, Lee JH, Lee SH: Molecular characterization of TEM-type $\beta$-lactamases identified in cold-seep sediments of Edison Seamount (south of Lihir Island, Papua New Guinea). J Microbiol 2005;43:172-178.

-Sogin ML, Morrison HG, Huber JA, Welch DM, Huse SM, Neal PR, Arrieta JM: Herndl GJ: Microbial diversity in the deep sea and the underexplored 'rare biosphere'. Proc Natl Acad Sci USA 2006;103:12115-12120.

Solbak AI, Richardson TH, McCann RT, Kline KA, Bartnek F, Tomlinson G, Tan X, ParraGessert L, Frey GJ, Podar M: Discovery of pectin-degrading enzymes and directed evolution of a novel pectate lyase for processing cotton fabric. J Biol Chem 2005;280: 9431-9438.

- Spits C, Le Caignec C, De Rycke M, Van Haute L, Van Steirteghem A, Liebaers I, Sermon K: Whole-genome multiple displacement amplification from single cells. Nat Protoc 2006;1:1965-1970.

-Steele HL, Streit WR: Metagenomics: advances in ecology and biotechnology. FEMS Microbiol Lett 2005;247:105-111.

-Stepanauskas R, Sieracki ME: Matching phylogeny and metabolism in the uncultured marine bacteria, one cell at a time. Proc Natl Acad Sci USA 2007;104:9052-9057.

Streit WR, Schmitz RA: Metagenomics - the key to the uncultured microbes. Curr Opin Microbiol 2004; 7:492-498.

Tang K, Utairungsee T, Kanokratana P, Sriprang R, Champreda V, Eurwilaichitr L, Tanapongpipat S: Characterization of a novel cyclomaltodextrinase expressed from environmental DNA isolated from Bor Khleung hot spring in Thailand. FEMS Microbiol Lett 2006;260:91-99.

Teeling H, Meyerdierks A, Bauer M, Amann R, Glöckner FO: Application of tetranucleotide frequencies for the assignment of genomic fragments. Environ Microbiol 2004;6:938947.

Torsvik V, Ovreas L, Thingstad TF: Prokaryotic diversity - magnitude, dynamics, and controlling factors. Science 2002;296:10641066.
Tyson GW, Banfield JF: Cultivating the uncultivated: a community genomics perspective. Trends Microbiol 2005;13:411-415.

Tyson GW, Chapman J, Hugenholtz P, Allen EE, Ram RJ, Richardson PM, Solovyev VV, Rubin EM, Rokhsar DS, Banfield JF: Community structure and metabolism through reconstruction of microbial genomes from the environment. Nature 2004;428:37-43

-Van der Wielen PW, Bolhuis H, Borin S, Daffonchio D, Corselli C, Giuliano L, D’Auria G, de Lange GJ, Huebner A, Varnavas SP, Thomson J, Tamburini C, Marty D, McGenity TJ, Timmis KN; BioDeep Scientific Party: The enigma of prokaryotic life in deep hypersaline anoxic basins. Science 2005;307:121123.

-Venter JC, Remington K, Heidelberg JF, Halpern AL, Rusch D, Eisen JA, Wu D, Paulsen I, Nelson KE, Nelson W, Fouts DE, Levy S, Knap AH, Lomas MW, Nealson K, White O, Peterson J, Hoffman J, Parsons R, Baden-Tillson H, Pfannkoch C, Rogers YH, Smith HO: Environmental genome shotgun sequencing of the Sargasso Sea. Science 2004;304:66-74.

Voget S, Steele HL, Streit WR: Characterization of a metagenome-derived halotolerant cellulose. J Biotechnol 2006;126:26-36.

Walter J, Mangold M, Tannock GW: Construction, analysis, and $\beta$-glucanase screening of a bacterial artificial chromosome library from the large-bowel microbiota of mice. Appl Environ Microbiol 2005; 71:23472354.

Wang C, Meek DJ, Panchal P, Boruvska N, Archibald FS, Driscoll BT: Charles TC: Isolation of poly-R-hydroxybutyrate metabolism genes from complex microbial communities by phenotypic complementation of bacterial mutants. Appl Environ Microbiol 2006;72: 384-391.

Wang G: Diversity and biotechnological potential of the sponge-associated microbial consortia. J Ind Microbiol Biotechnol 2006;33: 545-551.

Wenzel SC, Müller R: Recent developments towards the heterologous expression of complex bacterial natural product biosynthetic pathways. Curr Opin Biotechnol 2005; 16: 594-606.

Wexler M, Bond PL, Richardson DJ, Johnston AWB: A wide range-host metagenomic library from a waste water treatment plant yields a novel alcohol/aldehyde dehydrogenase. Environ Microbiol 2005;7:1917-1926.

Williamson JL, Borlee BR, Schloss PD, Guan C, Allen HK, Handelsman J: Intracellular screen to identify metagenomic clones that induce or inhibit a quorum-sensing biosensor. Appl Environ Microbiol 2005;71:63556344.

-Woese CR: Bacterial evolution. Microbiol Rev 1987;51:221-271. 
Woyke T, Teeling H, Ivanova NN, Huntemann M, Richter M, Gloeckner FO, Boffelli D, Anderson IJ, Gloeckner FO, Boffelli D, Anderson IJ, Barry KW, Shapiro HJ, Szeto E, Kyrpides NC, Mussmann M, Amann R, Bergin C, Ruehland C, Rubin EM, Dubilier N: Symbiosis insights through metagenomic analysis of a microbial consortium. Nature 2006; 443:950-955.

Y Yang H, To KH, Aguila SJ, Miller JH: Metagenomic DNA fragments that affect Escherichia coli mutational pathways. Mol Microbiol 2006;61:960-977.

-Yeates C, Blackall LL: Construction and analysis of a metagenomic library from an enhanced biological phosphorous removal biomass. Water Sci Technol 2006;54:277-284.
Yokouchi H, Fukuoka Y, Mukoyama D, Calugay $\mathrm{R}$, Takeyama H, Matsunaga T: Wholemetagenome amplification of a microbial community associated with scleractinian coral by multiple displacement amplification using $\$ 29$ polymerase. Environ Microbiol 2006;8:1155-1163.

Yooseph S, Sutton G, Rusch DB, Halpern AL, Williamson SJ, Remington K, Eisen JA, Heidelberg KB, Manning G, Li W, Jaroszewski L, Cieplak P, Miller CS, Li H, Mashiyama ST, Joachimiak MP, van Belle C, Chandonia JM, Soergel DA, Zhai Y, Natarajan K, Lee S, Raphael BJ, Bafna V, Friedman R, Brenner SE, Godzik A, Eisenberg D, Dixon JE, Taylor SS, Strausberg RL, Frazier M, Venter JC: The Sorcerer II Global Ocean Sampling Expedition: expanding the universe of protein families. PLoS Biol 2007;5:e16.
Yun J, Kang S, Park S, Yoon H, Kim MJ, Heu S, Ryu S: Characterization of a novel amylolytic enzyme encoded by a gene from a soil-derived metagenomic library. Appl Environ Microbiol 2004;70:7229-7235.

Zaballos M, López-López A, Ovreas L, Bartual SG, D’Auria G, Alba JC, Legault B, Pushker R, Daae FS, Rodríguez-Valera F: Comparison of prokaryotic diversity at offshore oceanic locations reveals different microbiota in the Mediterranean Sea. FEMS Microbiol Ecol 2006;56:389-405. 